\title{
Economically Deprived and Marginalized Scholars: Their Lifestyles, Experiences, Challenges and Aspirations
}

\author{
Bernardo A. Zabala ${ }^{1}$, Manuela P. Gutierrez ${ }^{2}$ \\ ${ }^{1}$ Graduate School, College of Nursing, Nueva Ecija University of Science and Technology, Cabanatuan City, Philippines \\ ${ }^{2}$ Graduate School, Nueva Ecija University of Science and Technology, Cabanatuan City, Philippines \\ Email: zbernardojr@yahoo.com, bernardozabalaJr@gmail.com,nein19ph@yahoo.com
}

How to cite this paper: Zabala, B.A. and Gutierrez, M.P. (2017) Economically Deprived and Marginalized Scholars: Their Lifestyles, Experiences, Challenges and Aspirations. Open Access Library Journal, 4: e3395.

https://doi.org/10.4236/oalib.1103395

Received: January 22, 2017

Accepted: February 20, 2017

Published: February 23, 2017

Copyright $\odot 2017$ by authors and Open Access Library Inc.

This work is licensed under the Creative Commons Attribution International License (CC BY 4.0).

http://creativecommons.org/licenses/by/4.0/

\begin{abstract}
Ambitious graduating secondary school students who belong to the marginalized sectors of the society apply to become scholars. The study focused on discovering the lifestyles, experiences, challenges and aspirations of the economically deprived and marginalized scholars who enrolled at Nueva Ecija University of Science and Technology System for A.Y. 2014-2015. Ten respondents who met the criteria were chosen. Qualitative research through a case study approach was utilized using purposive sampling. Ten were selected among 100 recommended samples that were considered as they passed the criteria. Prior consent was established from the samples. It was conducted in the province of Nueva Ecija and presently studying at Nueva Ecija University of Science and Technology, Cabanatuan City, Philippines. Frequency counts, percentage and weighted mean were utilized. Questionnaires, interviews, observations and focus group discussions were the instruments. Findings showed that the samples possessed individual differences on their lifestyles, experiences, challenges and aspirations.
\end{abstract}

\section{Subject Areas}

Sociology

\section{Keywords}

Social Science, Scholarship, Case Study, Nueva Ecija, Philippines

\section{Introduction}

This study reveals the conditions of scholars enrolled in the Nueva Ecija University of Science and Technology, particularly their lifestyles, experiences, chal- 
lenges and aspirations of the economically deprived and considers them as marginalized scholars. These scholars are ambitious who want to become somebody in the future with the same category with their peers and associates having good economic status as compared with them. These scholars according to them live in survival, depending on the support of significant others. Also they explore the strong family ties and social support as well as the government support to sustain their studies in college in order to fulfill their ambitions in life. These low income scholars tend to have long patience, positive attitudes about their economic status. It is noteworthy to look into these scholars so that significant others and government can give importance particularly on the financial, political, social and spiritual consideration.

As for the source, they are dependent on other sources of support. That they want to explore their brighter future through education is why they long for a better education as they consider poverty as their main reason why they are not economically good as their classmates who they are compared with.

Ambitious graduating secondary school students, who belong to the marginalized sectors of the society, apply to become scholars. The option employed by economically deprived and marginalized scholars is to avail of any scholarship grants to the deserving valedictorians, salutatorians, honor students, working students, political scholars, LGU Scholars, Scholar ng Bayan, and CHED scholars. Most often, scholars wanted to enjoy free tuition fees, board and lodging allowances, book and uniform allowances. Some scholars are employed in a fast food chain during their off hours, as a student's assistant at the school. There are scholars working during their vacant time so that they can gey money to sustain their financial burden. Some scholars avail loan, or qualify for grants or scholarships.

As the world enters the second decade of the 21st century, billions of people across the globe continue to suffer unspeakable misery due to a lack of access to sufficient food, clean water, basic shelter, and adequate medical care. According to the United Nations Millennium Report (2009) [1], more than 1.4 billion people live in "extreme poverty" (Department of Economic and Social Affairs of the United Nations Secretariat, 2009, p. 7) despite concerted international efforts to address structural, social, and economic inequalities that most severely impact the poor in developing nations. Many of these scholars claim that inter-country adoption is, at its core, a colonialist project in which infants and children from far-off lands are literally and figuratively produced for the consumption of Western elites (Hubinette T., 2006; Park Nelson, 2006). Dorow (2006), for example, writes [2].

Parents choose to adopt from China in part because of the imagined transformability of children's identities, made possible through legal and social "clean breaks" from birth family and birth country. These transformations are enacted by a political economy of material and symbolic values circulating through agencies, orphanages, officials, and 2 facilitators. But this is more than a specific way to reproduce the child, the parent, or the family. It produces children valued in particular ways for parents who are also valued in particular ways (p. 67). 
As cited by Eigsti, et al., language and pathology researchers (e.g. Geren, Snedeker, \& Ax, 2005; Glennen S. L., 2007; Glennen \& Masters, 2002; Krakow \& Roberts, 2003) have focused their attention on the 4 short-term and long-term impacts of sudden language change and the unique challenges associated with "arrested language development" (Glennen S., 2002, p. 333) among internationally-adopted children. Many of these studies (e.g. Glennen \& Masters, 2002; Schoenbrodt, Carran, \& Preis, 2007; Glennen S. L., 2007) represent attempts to develop clinical procedures for assessing and treating language delays among international adoptees. Language researchers have also been particularly interested in exploring English-language acquision by Chinese children because of the linguistic dissimilarities between the two languages (Krakow \& Roberts, 2003; Roberts, Pollock, Krakow, Price, Fulmer, \& Wang, 2005; Geren, Snedeker, \& Ax, 2005). Roberts, Pollock, Krakow, Price, Fulmer, \& Wang (2005), for example, conducted a study of Chinese adoptees and found that language acquisition "proceeds rapidly in the majority of preschool-age children adopted as infants and toddlers" (2005, p. 93). Geren, Snedeker, and Ax (2005) obtained similar results in a study of preschool-aged Chinese adoptees in which they concluded that Chinese adoptees acquire English language skills at essentially the same rate as native-born English-speaking children. In another study, Krakow and Roberts (2003) studied English language acquisition in a sample of Chinese infants and found that eleven of the fifteen children in their study had developed English language vocabularies at or slightly above the norm for native English-speakers by the time they had reached two years of age. Roberts, Pollock, and Krakow (2005) later investigated whether Chinese adoptees who had exhibited language delays in an earlier study would "catch up" (2005, p. 76) with their adopted peers after an additional two years of English language exposure. Although more than half of the children did show significant improvement in speech and language skills in the later study, all of the children who had initially exhibited language delays continued to lag behind their adopted peers [3].

Researchers have also explored English language acquisition and development among Russian and Eastern Europe adoptees, albeit with mixed results. Using a sample of 130 children, Glennen \& Masters (2002), for example, found that within approximately three years, children who had been adopted as infants had attained English language competency on par with native English speaking children of the same age, while children who had been adopted as toddlers were not far behind. However, as cited by Carter, Schoenbrodt, Carran, and Preis (2007) found that school-age adoptees continued to struggle with pragmatic language skills even after they had attained competency in other language skills. In another study, Glennen (2007) found that Eastern European toddlers who exhibited language delays at the time of their adoption were likely to exhibit continued language development delays one year later. Although scholars in a variety of fields have also explored the psychological, sociological, cultural, and legal implications of inter-country adoption, the most compelling challenges to inter-country adoption have been raised by critical scholars in the fields of anthropology (Do- 
row S., 2006; Hubinette T., 2006), sociology (Quiroz P. A., 2007; George, 2006; Freundlich, 2000; Herrmann \& Kasper, 1992), and law (O'Keefe, 2007; Smolin D. M., 2006). These scholars argue that the practice of inter-country adoption commodifies orphaned foreign children, transforming them into objects of value to be exchanged for money in the "transnational adoption marketplace (Park Nelson, 2006, p. 103). Even though these researchers generally agree that the inter-country adoption system commodifies orphaned children, none have explicitly addressed the relationship between the social inequities that permit children to be transformed into objects of trade and the discursive constructions that may help to facilitate such transformations. Yet, critical communication researchers have convincingly shown that a wide variety of organizations and social systems reproduce their social power by using language 6 patterns that circumvent discussion and open dialogue (Deetz S. A., 1992; 1985; Meares, Oetzel, \& Torres, 2004; Barker, 1993). A critical analysis of inter-country adoption industry discourse may thus provide some insight into the communication mechanisms by which the inter-country adoption system reproduces itself, perhaps at the expense of the children and families it claims to serve [2].

Others however are left to pay their own way by means of part time or full time employment. A great number of university scholars enrolled at the Nueva Ecija University of Science and Technology availed of the Provincial Scholarship Program which supports the poor but deserving students in the province. Scholars are categorized into need based, athletics, merit based, general and ethnicity based.

\section{Framework}

In consonance with the mandate of the Commission on Higher Education as provided for in Article XIV, Section 1 of the Philippine Constitution "to protect and promote the right of all citizens to quality education at all levels and shall take appropriate steps to make such education accessible to all" and Article XIV, Section 2(3) "to establish and maintain a system of scholarship grants, student loan programs, subsidies, and other incentives which shall be available to deserving students in both public and private schools, especially to the underprivileged", the Commission en Banc approved the Revised Implementing Guidelines for the CHED Student Financial Assistance Programs (StuFAPs) by virtue of Resolution No. 638-2012 dated December 19, 2012 [4].

The revised guidelines are to rationalize the administration and implementation of CHED Student Financial Assistance Programs (StuFAPs). It aims to select the poor and deserving scholars/grantees; ensure that the scholars/grantees are enrolled in duly authorized higher education institutions (HEIs) and in identified priority programs; and ascertain that the StuFAPs are properly administered and implemented (Figure 1).

\subsection{Scholarship Programs}

FULL MERIT (FS). This refers to the State Scholarship Program (SSP) intended 


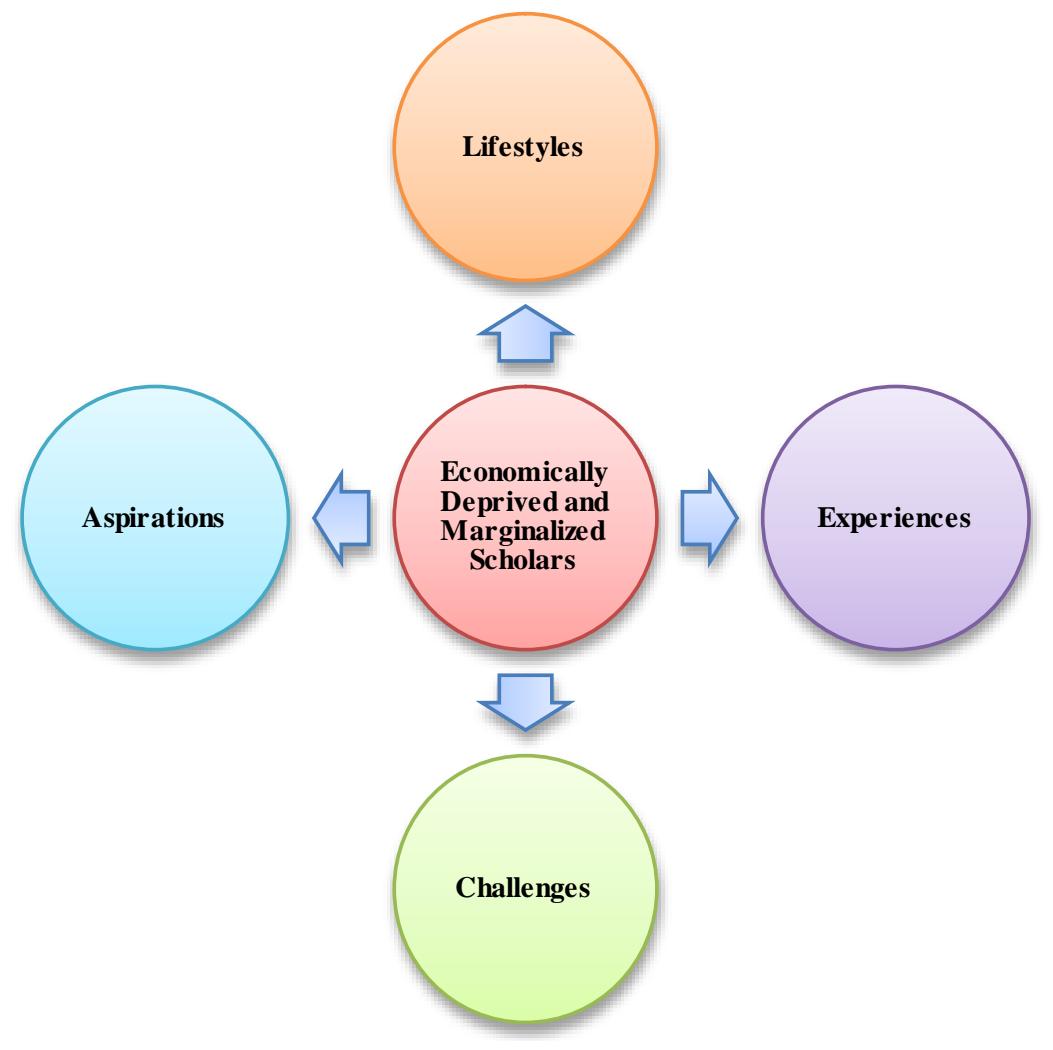

Figure 1. Conceptual framework.

for graduating high school students whose general weighted average (GWA) is at least $90 \%$ in the third year and at least $90 \%$ in the first three grading periods of the fourth year, enrolled either in public or private HEIs (Php30000.00).

HALF MERIT (HS). This refers to the Private Education Student Financial Assistance (PESFA) intended for graduating high school students whose GWA is at least $85 \%$ in the third year and at least $85 \%$ in the first three grading periods of the fourth year. They are to enroll in degree programs in private HEIs (Php15000.00).

The above scholarship programs can also be availed by students belonging to the following: persons with disabilities (PWDs), solo parents and their dependents, members of cultural minorities, members of the hill tribes and senior citizens, if qualified [5].

\subsection{Grant-in-Aid Programs}

TULONG DUNONG (TD). This is intended for graduating high school students whose GWA is at least $80 \%$ in the third year and at least $80 \%$ in the first three grading periods of the fourth year. This program can be availed by students belonging to the following: persons with disabilities (PWDs), solo parents and their dependents, members of cultural minorities, members of the hill tribes and senior citizens, if qualified (Php12000.00).

DND-CHED-PASUC STUDY GRANT (DCP). This is intended for qualified dependents of military personnel of the Armed Forces of the Philippines who 
were killed in action, discharged due to complete disability combat related and those who are in active service subject to admission requirements of accepting State Universities and Colleges (SUCs). The specific guidelines pertaining thereto are contained in the Implementing Rules and Regulations of the Department of National Defense (DND)-CHED_Philippine.

Association of State Universities and Colleges (PASUC) (Php5000.00).

OPAPP-CHED Study Grant Program. This is intended for authenticated or amnestied former rebel and individual members of groups with existing peace agreements with the government or their next of kin who cannot afford to study in college due to financial constraints. Only one slot can be availed by the qualified former rebel or his/her designated qualified next of kin beneficiary. The specific guidelines pertaining thereto are contained in the Joint Memorandum Circular of CHED and The Office of Presidential Adviser on Peace Process (OPAPP) (Php10000.00).

CHED Special Study Grant Program for Congressional Districts (CSSGPCD). This is intended for poor and deserving students from the different Congressional Districts and those recommended by Party lists. They are to enroll in degree programs at any curriculum year level, preferably in public HEIs (Php5000.00).

CHED SENATE STUDY GRANT PROGRAM (CSSGP). This is intended for poor and deserving students selected by the Office of the Senators. They are to enroll in degree programs at any curriculum year level, preferably in public HEIs (Php5000.00) [6].

Scholarship is a financial award given to students that qualify to the requirements set by a donor. "As money and resources become more scarce for college students, jobs become more of a necessity rather than an after school activity. Any changes to students' routines will lead to changes in academics, whether they are positive or negative" (Shuey, 2008) [7]. As more students are employed, they face having to balance their academic requirements, extracurricular activities, and employment responsibilities to maintain their lifestyles (Furr \& Elling, 2009) [8].

Filipino working students can be categorized into two groups: those who primarily identify themselves as students but who work in order to pay the bills and those who are first and foremost workers who also take some college classes. Almost two-thirds of undergraduates who work consider themselves "students who work"; the other third consider themselves "workers who study" (J. Orszag, P. Orszag, and Diane M. Whitmore, 2001) [9].

The financial burden of college tuition is significant and rising. In light of the increasing price of college, education, many families are facing significant challenges in financing their children's education. The evidence shows that as one response to the financial burden of college tuition, students are working more while in college. Over 60 percent of college students report that their parents now expect them to work during the school year to help cover expenses. More students are working, and more are working longer hours (Diane M. Whitmore, 2001) [9].

Scholarship programs in the Philippines come in many forms. The most popular among college students is the Entrance Scholarship, wherein successful ap- 
plicants are fully or partially exempted from paying tuition fees for a semester or a year. Most private schools implement an Entrance Scholarship program, although the level of scholarship (full, partial) and the period of implementation (semestral, annual) vary from one school to another. For example, a high school valedictorian of a class composed of 50 or more graduates is entitled to a oneyear free tuition while the salutatorian of the same class can avail of a 50 percent discount on tuition fees.

There is also the so-called Study Now, Pay Later scheme where students were allowed to finish their studies and get a job first before settling the cost of their education. Students who excel in singing, dancing, and dramatics may apply for Cultural Scholarship who, after qualifying through an audition, can avail of tuition discount from $25 \%$ to $100 \%$. Those who are part of the school's varsity team are entitled to Athletic Scholarship provided that they have shown and proven exemplary performance in sports competitions and have satisfactory academic grades. Athletes enjoy $25 \%$ to $100 \%$ discount on tuition fees (in some cases, including allowances and miscellaneous fees) depending on their qualifications.

Students who have passed the entrance examination in State Colleges and Universities are referred to as Iskolarng Bayan. Tuition fees in these institutions are either fully or partially subsidized by the government. Another form of scholarship is the Grant-in-aid Scholarship. This scholarship is made available to students who belong to a low-income family but show satisfactory performance in academic subjects. These students are given work assignments in the different offices of the school. They avail tuition discounts from 50\% to $100 \%$ which commensurate to the number of hours rendered for a week.

Furr and Elling (2007) also found that upperclassmen worked more hours than freshmen, indicating that the older students would be more likely to suffer in their academics [7]. Therefore, working full time has an even greater impact on academics because, often times, working 40 or more hours further decreases a student's college grade point average (GPA) and is negatively related to completion of a bachelor's degree (Astin, 2006) [8].

Students managed to engage in multiple social, employment and financial obligation as they finish their studies. It was discovered that paid work should be viewed as an essential aspect of life that enables students to continue with academics rather than an obstruction to studies. Students were able to display a good understanding of stressful factors on academic staff and emphasized on communication of prospect that criticizing academic staff (Massingham 2006). While students approach has many issues that pertains their study/work/life management, they revealed aspirations for more learning, recognizing skills and insights which are offered by strong immersions in a definite activity or topic.

As the name suggests, need based scholarships are those that are awarded to students who need them. These scholarships may cover the entire costs of a student's education, or they may cover only a portion of it. The goal of a need based scholarship is to help students from low income families get a quality education. However, need based scholarships are different from financial aid. Even students 
who come from low income families will be expected to meet a certain level of academic success, and after they've been awarded the scholarship, they will be required to maintain a certain GPA. A scholarship is a great way to get a free education, without having to worry about paying back loans after graduation.

\subsection{Objectives of the Study}

This study aimed to determine the different lifestyles, experiences, challenges and aspirations of the economically deprived and marginalized scholars who enrolled at Nueva Ecija University of Science and Technology for A.Y. 2014- 2015.

\section{Methodology}

The qualitative type of research through a case study approach was utilized using purposive sampling. Survey questionnaires, interviews, observations and focus group discussion were the instruments used to verify and confirm the data gathered by the researcher. Utmost confidentiality of the data gathered was observed. Prior consent from the respondents was sought prior to the conduct of the study.

\subsection{The Respondents}

Ten respondents were selected among 100 recommended samples that were considered as they passed the criteria such that they must belong to economically deprived and marginalized family as recommended by barangay officials, teachers, and respected citizen in the community and personally inspected and confirmed by the researcher. Their parents' income shall fall under below economic level, graduated valedictorian in high school. Five males and five females were chosen, eager and wanted to pursue their tertiary education.

\subsection{Study Locale}

The study locale covers the four Congressional Districts of Nueva Ecija, Philippines.

\subsection{Procedure of Analysis}

Qualitative research through a case study approach was utilized using purposive sampling. Survey questionnaires, interviews, observations focus group discussion were the instruments used. The respondents used pseudo name in the pre- sentation of data. Other sources of data were barangay officials, high school teachers of the respondents, respected residents of the respondents, their parents, and neighbors of the respondents Frequency count, Percentage and weighted mean were used as statistical tool.

\section{Results and Discussion}

\subsection{Profile of the Respondents}

The respondents ranged from 15 - 16 years old, graduated as class Valedictorians, 
five males and five females, and graduated in public secondary schools. They belong to economically deprived and marginalized family. Their parents do not have stable job, earned an average net income of 5,000 pesos - 10,000 pesos monthly. They live in shanty with limited appliances.

\subsection{Lifestyles}

"Studying my lessons is my hobby" (WM = 5.0), "I am interested in school activities" (WM = 4.8), "I am a time conscious person" (WM = 4.9), "I attend my class everyday" ( $\mathrm{WM}=5.0)$, "I prepare my assignments ahead of time" (WM = 4.8 ), "I study my lesson before I sleep" (WM $=5.0)$, "I attend party with my friends" (WM = 3.8), "I prefer to work with my friends" (WM = 4.3), "I always pray to God to enlightened me in my decisions" $(\mathrm{WM}=5.0)$, "I prefer to stay at home during weekend and prepare my school requirements" (WM $=4.6)$, "I prefer to read books and reading material during my leisure time" $(\mathrm{WM}=4.4)$, "I develop more close development with my parents, friends" and relatives" (WM $=4.4$ ), "I socialized with friends when there is an occasion at school or family social activity" ( $\mathrm{WM}=4.6$ ), "I set aside my personal relationship with my suitor" (WM = 4.1), "I always maintain my relationship with God" ( $\mathrm{WM}=5.0)$.

The respondents lifestyles have similarities as they keep maintain their relationship with the creator, seek guidance from above to enlighten their decisions, develop themselves to study their lessons as their hobby, participated in school activities such as programs, sports and physical development and other extra- curricular activities. They keep their selves prepare in their class activities such as class recitations, quizzes, examinations and semester requirements. They keep maintain socialized with friends, parents, and relatives. They keep developing and improving themselves worthy for their future.

During the interview it was disclosed that since they became scholar they learned to be productive, cooperative and committed in school, at home and in the community. Changes affected their personal, social and spiritual activities. They also stated that they developed refinement of their character, social contact and attitude towards their work.

During the focus group discussions, the scholars, when asked what lessons learned from their lifestyles that made them different compared when they were an ordinary students. Accordingly Case A revealed that he transformed his attitude particularly in his study habits that he study his lessons every day, look into his assignment daily, do advance reading, participating in class activities and most is reading his advance lessons before he sleeps and after waking up early in the morning. Some have common lifestyle experiences such as feeling bored if their lesson is new and when they were not familiar with it. Few said that their lifestyle did not change because they usually do what they were doing.

\subsection{Experiences}

"I experienced long line of waiting for the document signing" ( WM $=4.3)$, "I enrolled the course that I wanted to enroll" ( $\mathrm{WM}=5.0$ ), "I submitted a certifica- 
tion of low income family" ( $\mathrm{WM}=4.9)$, "I feel happy as scholar" ( $\mathrm{WM}=5.0)$, "My high school mates greeted me most of the time" (WM = 5.0), "I am eager to study my lessons well" (WM = 5.0), "My self-esteem is very high" (WM = 4.9), "I am pressured by my semester requirements" (WM = 4.7), "I participated in extracurricular activity of the department" (WM = 4.7), "I developed self-confidence, and independence" ( $\mathrm{WM}=4.5)$, "I developed myself to participate in the class discussion" (WM = 4.5), "I developed positive attitude in participating school activity" (WM $=4.9$ ), "I develop myself to be accommodating person" ( $\mathrm{WM}=4.6)$, "I work during weekend to have a weekly allowance" ( $\mathrm{WM}=4.2)$, "I am very proud and boost my morale" (WM $=4.3)$.

The respondents had varied experiences during the calendar year to wit: experienced long waiting time for signing of documents, submitted requirements for their scholarships, felt happy as they had greeted by their friends and previous schoolmates, studied their lessons well, developed self-esteem, pressured by my semester requirements, and participated extracurricular activities in the college department.

During the interview they revealed that their experiences were very tough to them. They developed strong sense of responsibilities and commitment for their future. They also admitted that their experience may not be true to ordinary students. Their experiences had something to do for development as a leader in the near future.

During the focus discussion when asked what transpired from their experiences; they reacted that they had a very challenging experiences. They averred that shyness was nowhere to find. They developed self-confidence, leadership qualities and traits. They also claimed that even they belong to economically deprived and marginalized family they were given the opportunity to prove their selves. According to some, they were elated of their experiences in the college because it is great deal.

\subsection{Challenges}

"Financial assistance is not enough to pay my semester expenses" (WM = 5.0), "Delay of fund support from the sponsors, that resulted to no permit no exam policy of the university" (WM $=5.0$ ), "Submission of grades before I can avail of financial assistance" ( $\mathrm{WM}=5.0)$, "I passed the special examination before I was accepted as scholar" (WM = 5.0), "Long line was experienced in the renewal of scholarship grants" (WM = 5.0), "Repetition of requirements for every semester" (WM = 5.0), "it boost my morale as scholar" ( $\mathrm{WM}=5.0)$, "I feel happy and challenged" ( $W M=5.0)$, "I am eager to finish my course" ( $W M=5.0)$, "I developed my sense of responsibility" ( $\mathrm{WM}=5.0)$, "I am optimistic to finish my course" (WM = 5.0), "I am pressured by my hectic schedule" (WM = 4.7), "I am pressured of my grade" ( WM $=5.0)$, "I am pressured the requirements for the scholars" ( $\mathrm{WM}=4.9)$, "The delay of releasing of grades pressured me" ( $\mathrm{MW}=$ 5.0 ), "I am pressured for the delay of scholars support fund" ( $\mathrm{WM}=5.0$ ), "I exerted extra effort to maintain my grades" (WM $=5.0)$, "I feel inferior because I 
belong to a marginalized family" ( $W M=5.0)$, "I am pressured because I do not have a backup" (WM $=4.5)$, "I consider scholarship as political ploy" (WM = 4.5).

The financial assistance of the scholars is not enough to support their semester expenses; thereby they resulted from usurious loans. The respondents were challenged on the late issuance of their scholar fund support from the sponsoring agency, late submission of grades delayed them to claim their fund support, and tedious preparing of documents challenged the scholars. They were challenged to take their turns to long queues during the renewal of scholarship grants. They developed themselves to be responsible, optimistic although they were pressured of their schedules. They felt inferior being a marginalized family. They were challenged to maintain their grades.

As exposed during the interview, they emphasized that take the fund support did not arrive on time so they were forced to loan from their relatives to pay their tuition fee, they promised to pay once the scholar support fund released to them. Some of them claimed that they were challenged to some of their professor's strictness in class activities in class recitations, quizzes and assignments. Case B, and Case C shared their challenges when their professor scolded them because they got low scores during their quiz. Case $\mathrm{E}$ shared that he was forced to work at food chain so that he could sustain his daily allowance. Other scholars learned lessons from their challenging experiences.

During the focus group discussions, the scholars when asked about their challenges encountered being a scholar; they averred that they were challenged on the long queues during renewal of their scholarship requirements. Their financial support fund was not enough to sustain their daily requirements in going to school because of very expensive boarding house and expensive meals. Case G revealed that sometimes he ate twice a day only because his allowance was not enough for his needs. According to him there was no place for thrift and frugality if you don't have money to manage. Case J declared that his salary for being a part time employee at a fast food chain helped him sustain his needs, however according to him he felt sleepy during his class and he had hard time meeting his schedules and requirement.

\subsection{Aspirations}

"I want to become rich" (WM = 5.0), "I want that I be idolized by younger generation" (WM $=5.0)$, "I want to marry a rich business tycoon" (WM = 5.0), "I want to repay my parents sacrifice" (WM $=5.0)$, "I want to prove to my sponsor that I really deserve the scholarship given to $m e$ " $(\mathrm{WM}=5.0)$, "I want to become a great politician" ( $\mathrm{WM}=3.4)$, "I want to become a lawyer" (WM = 3.3), "I want to go abroad for money" ( $\mathrm{WM}=3.8)$, "I want to put up a medium scale business for my family" ( $\mathrm{WM}=3.8$ ), "I want to become an educator" ( $\mathrm{WM}=3.6)$, "I want to join the AFP" (WM = 3.0), "I want to join the PNP" (WM = 2.8), "I want to manage a five star hotel" (WM =3.0), "I want to be a good parent of my children" (WM $=4.9)$, "I want to be a fulfilled individual someday" $(\mathrm{WM}=5.0)$. 
The respondents wanted to become rich, idolized by younger generation, marry a rich business tycoon, and repay their parents sacrifice, prove that their donor deserve the money worth for them, wanted to be fulfilled, good parents of their children, to go abroad for money, put up small scale business, to become educator, to become politician, wanted to join the AFP and the PNP.

During the interview, Case A, aspires to become a AAA Contractor and Manager, Case B, desires to become an owner of import and export trading business, Case $\mathrm{C}$, wants to manage a five star hotel, Case D, wishes to become a school manager, Case E, desires to become a well-known architect, Case F, longs to become a PNP Officer, Case G, hope to become a well-paid programmer and Information technologist, Case $\mathrm{H}$, wishes to become a rich Nurse, Case I, desires to put up medical laboratory and become a chemist, while Case J, wants to join the Corps of Engineers of the AFP.

The respondents had varied aspirations. They wanted to be known someday by the people because most of them came from rugs. They wanted to show that their sacrifices would be compensated and would have brighter future.

The respondents were observed to maintain their personal lifestyles, they behaved properly, they felt relax to accept challenges in life. They attended their classes on time, they prepared themselves in class activities like quizzes, recitation and prepare their assignment independently and participated during group activities.

\section{Conclusions}

The respondents' lifestyles had similarities as they kept maintaining their relationship with the Creator. They had developed themselves to study their lessons as their hobby and participated in school activities. They kept themselves prepared in their class activities such as class recitations, quizzes, examinations and semester requirements. The financial assistance of the scholars was not enough to support their semester expenses, thereby resulting in usurious loans. The respondents were challenged on the late issuance of their scholar fund support from the sponsoring agency; late submission of grades delayed them claiming their fund support, and tedious preparing of documents.

The scholars expected that the financial assistance was instant, however, that there are long processes to be done. Then, it causes the delay of the financial assistance, thus it is not given in time.

\section{Recommendation}

1) Scholarship grants should be released on time, so that scholars will not be bothered in the university policy of no exam no permit.

2) Scholarship donor shall deliver on time the benefit due to the scholars.

3) Scholars shall pick out the good lessons learned from their experiences as their guiding principles and conquer solutions of the challenges they encountered.

4) Scholars shall develop patience and tolerance and keep in mind of their as- 
pirations in life so that they will succeed.

5) A related study shall be undertaken on aspect not covered in this study.

\section{References}

[1] United Nations Millenium Report (2009) The Millennium Development Goals Report. http://www.un.org/millenniumgoals/pdf/MDG_Report_2009_ENG.pdf

[2] Carter, D.L. (2011) Multimodal Critical Discourse Analysis of Systematically Distorted Communication in Inter Country Adoption Industry.

https://research.libraries.wsu.edu/xmlui/bitstream/handle/2376/3502/Carter_wsu_0 251E_10296.pdf?sequence $=1$

[3] Eigsti, I.-M., et al. (2011) Language and Cognitive Outcomes in Internationally Adopted Children. Development and Psychopathology, 23, 629-646.

https://doi.org/10.1017/S0954579411000204

http://eigsti.psy.uconn.edu/wp-content/uploads/sites/664/2014/05/Eigsti_IntAdop_= 2011.pdf

[4] Article XIV, Section $1 \& 2$ of Philippine Constitution, The 1987 Constitution of the Republic of the of the Philippines-Article XIV Education, Science and Technology, Arts, Culture and Sports.

http://www.gov.ph/constitutions/the-1987-constitution-of-the-republic-of-the-phili ppines/the-1987-constitution-of-the-republic-of-the-philippines-article-xiv/

[5] CHED Memorandum Order No. 56, Series of 2012, Resolution No. 638-2012, Revised Implementing Guidelines for the Student Financial Assistance Programs (StuFAPS) of the Commission on Higher Education (CHED). http://www.ched.gov.ph/wp-content/uploads/2013/07/CMO-No.56-s2012.pdf

[6] CHED Memorandum, Student Financial Assistance Programs (StuFAPs), Commission on Higher Education, Office of Student Services.

http://www.ched.gov.ph/wp-content/uploads/2013/09/Student-Financial-Assistance -Programs-StuFAPs-CMO-No.56-s.-2012.pdf

[7] Barbara, S. (2008) Classroom Management. http://www.education.com/reference/article/classroom-management/

[8] Watanabe, L.E. (2009) The Effects of College Student Employment on Academic Achievement. http://www.urj.ucf.edu/vollissue1/watanabe/literature.php

[9] Cascio, E.U. and Schanzenbach, D.W. (2013) The Impacts of Expanding Access to High-Quality Preschool Education. Brookings Papers on Economic Activity: 127192. https://doi.org/10.1353/eca.2013.0012 https://www.brookings.edu/ /media/Projects/BPEA/Fall\%202013/2013b_cascio_pr eschool_education.pdf 
Submit or recommend next manuscript to OALib Journal and we will provide best service for you:

- Publication frequency: Monthly

- 9 subject areas of science, technology and medicine

- Fair and rigorous peer-review system

- Fast publication process

- Article promotion in various social networking sites (LinkedIn, Facebook, Twitter, etc.)

- Maximum dissemination of your research work

Submit Your Paper Online: Click Here to Submit

Or Contact service@oalib.com 